\title{
OPEN Amikacin potentiator activity of zinc complexed to a pyrithione derivative with enhanced solubility
}

\author{
Jesus Magallon, Peter Vu, Craig Reeves, Stella Kwan, Kimberly Phan, \\ Crista L. Oakley-Havens, Kenneth Rocha, Veronica Jimenez $₫$, María Soledad Ramirez $\mathbb{D}$ \& \\ Marcelo E. Tolmasky
}

Resistance to amikacin in Gram-negatives is usually mediated by the $\mathbf{6}^{\prime}-\mathrm{N}$-acetyltransferase type lb [AAC $\left(6^{\prime}\right)-\mathrm{lb}$, which catalyzes the transfer of an acetyl group from acetyl CoA to the $6^{\prime}$ position of the antibiotic molecule. A path to continue the effective use of amikacin against resistant infections is to combine it with inhibitors of the inactivating reaction. We have recently observed that addition of $\mathrm{Zn}^{2+}$ to in-vitro enzymatic reactions, obliterates acetylation of the acceptor antibiotic. Furthermore, when added to amikacin-containing culture medium in complex to ionophores such as pyrithione (ZnPT), it prevents the growth of resistant strains. An undesired property of ZnPT is its poor watersolubility, a problem that currently affects a large percentage of newly designed drugs. Watersolubility helps drugs to dissolve in body fluids and be transported to the target location. We tested a pyrithione derivative described previously (Magda et al. Cancer Res 68:5318-5325, 2008) that contains the amphoteric group di(ethyleneglycol)-methyl ether at position 5 (compound 5002), a modification that enhances the solubility. Compound 5002 in complex with zinc (Zn5002) was tested to assess growth inhibition of amikacin-resistant Acinetobacter baumannii and Klebsiella pneumoniae strains in the presence of the antibiotic. Zn5002 complexes in combination with amikacin at different concentrations completely inhibited growth of the tested strains. However, the concentrations needed to achieve growth inhibition were higher than those required to achieve the same results using ZnPT. Time-kill assays showed that the effect of the combination amikacin/Zn5002 was bactericidal. These results indicate that derivatives of pyrithione with enhanced water-solubility, a property that would make them drugs with better bioavailability and absorption, are a viable option for designing inhibitors of the resistance to amikacin mediated by $\mathrm{AAC}\left(6^{\prime}\right)-\mathrm{Ib}$, an enzyme commonly found in the clinics.

Water-solubility helps drugs dissolve in body fluids and be transported to the target location ${ }^{1}$. Unfortunately, about half of the chemical compounds identified as potential new medicines are poorly soluble in water ${ }^{2,3}$. Currently, many efforts and techniques focus on enhancing the water-solubility of lead compounds, which illustrates this property's importance for pharmacological tools ${ }^{1-7}$.

Studies to isolate inhibitors of aminoglycoside-modifying enzymes, in particular the aminoglycoside $6^{\prime}-\mathrm{N}$-acetyltransferase type Ib [AAC $\left(6^{\prime}\right)$-Ib], a widely distributed enzyme that specifies resistance to the semisynthetic amikacin ${ }^{8-10}$, showed that $\mathrm{Zn}^{2+}$ complexed to pyrithione (ZnPT) (Fig. 1) counter the action of AAC $\left(6^{\prime}\right)$-Ib in bacterial cells in culture ${ }^{11,12}$. Consequently, combinations amikacin/ZnPT produced a substantial reduction in the minimal inhibitory concentration of amikacin of AAC(6')-Ib-containing Acinetobacter baumannii, Escherichia coli, Enterobacter cloacae, and Klebsiella pneumoniae isolates ${ }^{11-14}$. However, complexes formed between pyrithione and divalent metal cations, which occur through the oxygen and sulfur atoms, have very low solubility in aqueous solvents, impairing bioavailability ${ }^{15}$. To deal with this limitation, Magda et al. designed pyrithione derivatives with substitutions at position 5 to enhance their solubility in aqueous solvents ${ }^{7}$. Here, we show that a complex formed between a water-soluble pyrithione derivative, compound 5002, and $\mathrm{Zn}^{2+}$ ( $\mathrm{Zn} 5002$ ) (Fig. 1) exhibits amikacin resistance inhibitory properties similar, albeit not as robust, to those observed when testing $\mathrm{ZnPT}$. 


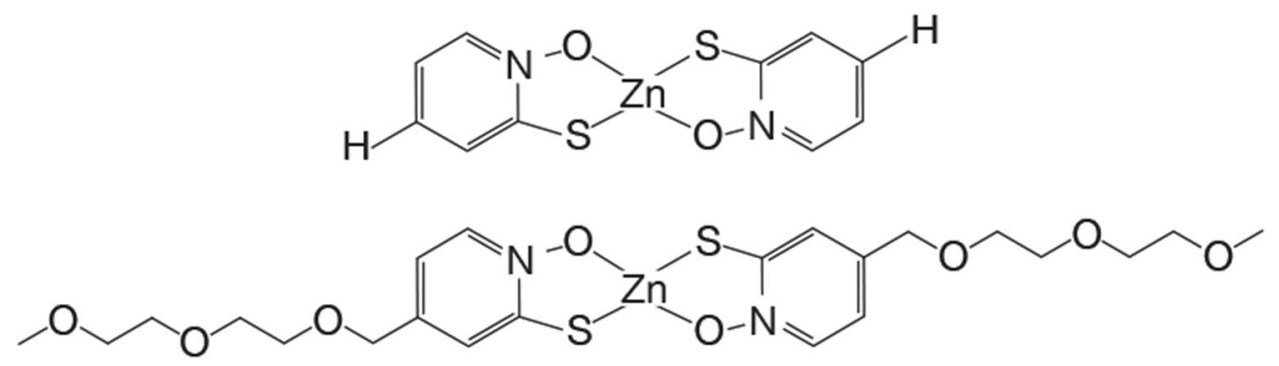

Figure 1. Zn5002 and ZnPT complexes chemical structures. Chemical structures of ZnPT (upper) and Zn5002 (lower).

\section{Results}

The addition of $\mathrm{Zn}^{2+}$ to reaction mixtures containing $\mathrm{AAC}\left(6^{\prime}\right)-\mathrm{Ib}$ and aminoglycosides known to be substrates for this enzyme exerts a strong inhibition effect of the antibiotic's acetylation ${ }^{12}$. However, inhibition of resistance in cells in culture requires very high concentrations of zinc salts in the culture medium. The concentrations of zinc ions required to reverse resistance can be drastically reduced supplementing the growth medium with the complex $\mathrm{ZnPT}{ }^{11,12}$. An inconvenience to develop $\mathrm{ZnPT}$ as an adjuvant to aminoglycosides to treat resistant bacteria is its poor solubility in water. Previous work by Magda et al. showed that substituting the hydrogen at position 5 of pyrithione by some amphoteric chemical groups results in derivatives with higher water-solubility that can still diffuse across the membrane $e^{7}$. We synthesized compound 5002, in which the hydrogen at position 5 is replaced by di(ethyleneglycol)-methyl ether group (Fig. 1). This compound was complexed to $\mathrm{Zn}^{2+}(\mathrm{Zn} 5002)$ and tested as a potentiator to amikacin to overcome resistance in $\mathrm{AAC}\left(6^{\prime}\right)$-Ib-carrying A. baumannii, and K. pneumoniae cells.

All four strains tested were cultured in the presence of amikacin, the ionophore-zinc complex, or a combination of both compounds at different concentrations. Figure 2 shows the growth curves corresponding to the combinations that include the minimum possible concentration of each component to inhibit growth completely. The figure also shows that when none or only one of the components was used to supplement the Mueller-Hinton broth there was healthy bacterial growth. Although the concentrations required to inhibit growth vary from strain to strain, there was an appropriate combination in all cases such that the individual components did not impede growth. It can also be noted that the $\mathrm{ZnPT}$ concentration necessary to overcome the resistance to amikacin is consistently lower than that of Zn5002.

The results obtained in the experiments described above indicate that the complex Zn5002, as we showed before for $\mathrm{ZnPT}$, is responsible for the phenotypic conversion to amikacin susceptibility in bacterial pathogens harboring the resistance enzyme AAC $\left(6^{\prime}\right)$-Ib. However, these experiments did not inform about the bactericidal or bacteriostatic effect of the combination. Therefore, we carried out time-kill assays to confirm that the inhibition of growth observed in the presence of Zn5002 and the antibiotic is due to a bactericidal effect. For comparison, we carried out another series of assays using amikacin and ZnPT. Figure 3 shows that the addition of amikacin and $\mathrm{Zn} 5002$ or ZnPT is followed by rapid loss of bacterial cell viability. Conversely, addition of amikacin or zinc-ionophore alone did not result in cell death. These assays showed that amikacin has a robust bactericidal activity on the AAC(6')-Ib-carrying A. baumannii A144, A155, A118(pJHCMW1), and K. pneumoniae JHCK1 strains when administered in combination with the complexes.

\section{Discussion}

Water-solubility is a desirable characteristic of drugs for enhanced bioavailability ${ }^{2,3}$. Various routes of administration, such as oral or parenteral, depend on the drug water solubility to be viable options ${ }^{5,16}$. Drugs that readily dissolve in the aqueous body fluids are more efficient in reaching the desired concentrations, being transported to, and reaching their target ${ }^{1}$. These characteristics make them therapeutically effective without the need to use high doses that could be the cause of secondary effects ${ }^{1}$. Conversely, low water-solubility is the cause of failure of numerous drug candidates ${ }^{1}$.

Amikacin is an aminoglycoside most commonly administered intravenously and intramuscularly, yet other routes are also utilized, such as intrathecal, intraventricular, topical, and inhaled ${ }^{8,17,18}$. In our quest to identify compounds that inhibit the $\mathrm{AAC}\left(6^{\prime}\right)$-Ib amikacin-disabling action, we recently found that various cations effectively interfere with the enzymatic inactivation ${ }^{11,12,19-21}$. In the case of $\mathrm{Zn}^{2+}$, the concentrations needed to inhibit growth of amikacin-resistant cells in the presence of the antibiotic are significantly reduced if the cation is added to the growth media in complex with ionophores ${ }^{11-13,20-22}$. A very effective complex to reduce amikacin resistance levels in various bacteria is $\mathrm{ZnPT}$, a compound already being researched and repurposed for cancer treatments and that has low toxicity when tested on mice ${ }^{23,24}$. After $\mathrm{ZnPT}$ was shown to be effective in reversing resistance to amikacin and other aminoglycosides in diverse bacteria, several ionophore and zinc-ionophore complexes were also shown to enhance antibiotic activity through other mechanisms including zinc ions interfering with metal homeostasis ${ }^{25-28}$. Our results do not discard that zinc can act at multiple levels, but since we demonstrated that $\mathrm{Zn}^{2+}$ inhibits the acetylation reaction mediated by AAC $\left(6^{\prime}\right)$-Ib in vitro, and in experiments on bacterial cells in culture the ZnPT concentrations used practically do not impair growth but act as adjuvants to amikacin, we conclude that inhibition of the enzymatic inactivation of amikacin is one of the mechanisms by which the complex enhance the action of the antibiotic. 

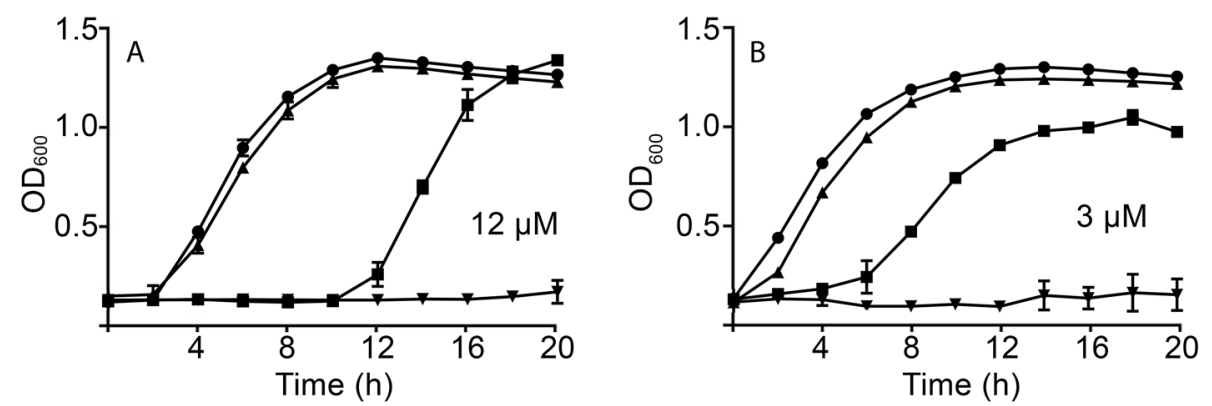
$\rightarrow$ None
$\rightarrow 16 \mu \mathrm{g} / \mathrm{ml}$ AMK
- Zn5002 (A) or ZnPT (B)
$+16 \mu \mathrm{g} / \mathrm{ml}$ AMK + Zn5002 (A) or ZnPT (B)

Acinetobacter baumannii A155
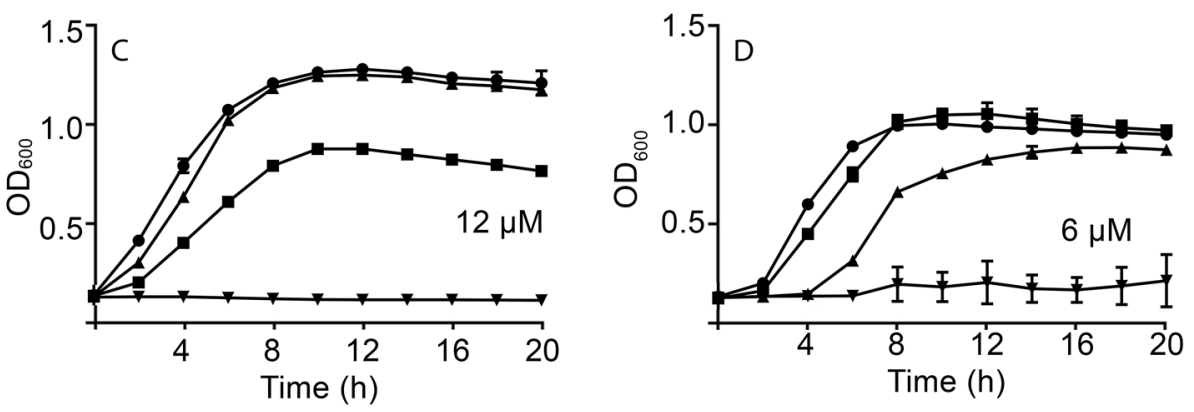

$\rightarrow$ None

$-16(\mathrm{C})$ or 8 (D) $\mu \mathrm{g} / \mathrm{ml}$ AMK

- Zn5002 (C) or ZnPT (D)

* 16 (C) or 8 (D) $\mu \mathrm{g} / \mathrm{ml}$ AMK + Zn5002 (C) or ZnPT (D)

Acinetobacter baumannii A118(pJHCMW1)
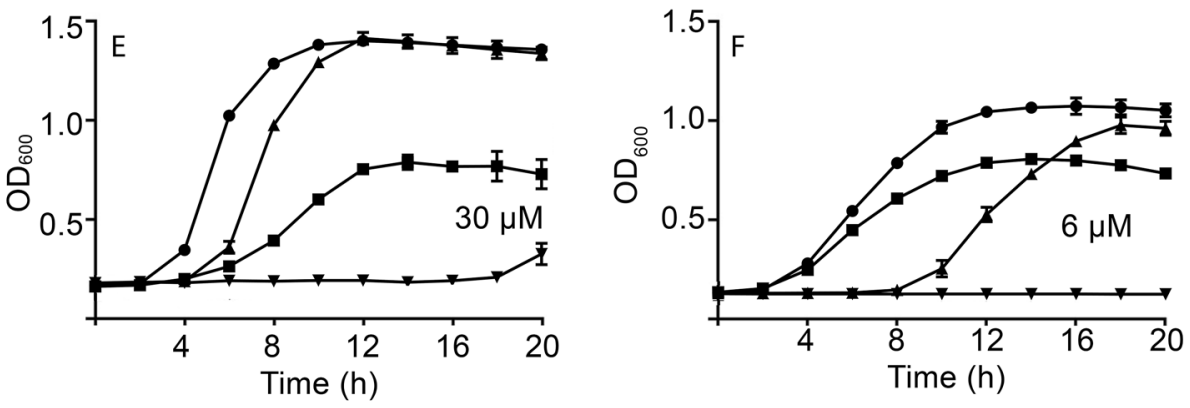

$$
\begin{aligned}
\rightarrow & \text { None } \\
- & 8 \mu \mathrm{g} / \mathrm{ml} \text { AMK } \\
+ & \text { Zn5002 (C) or ZnPT (D) } \\
+ & 8 \mu \mathrm{g} / \mathrm{ml} \text { AMK }+ \\
& \text { Zn5002 (C) or ZnPT (D) }
\end{aligned}
$$

Klebsiella pneumoniae JHCK1
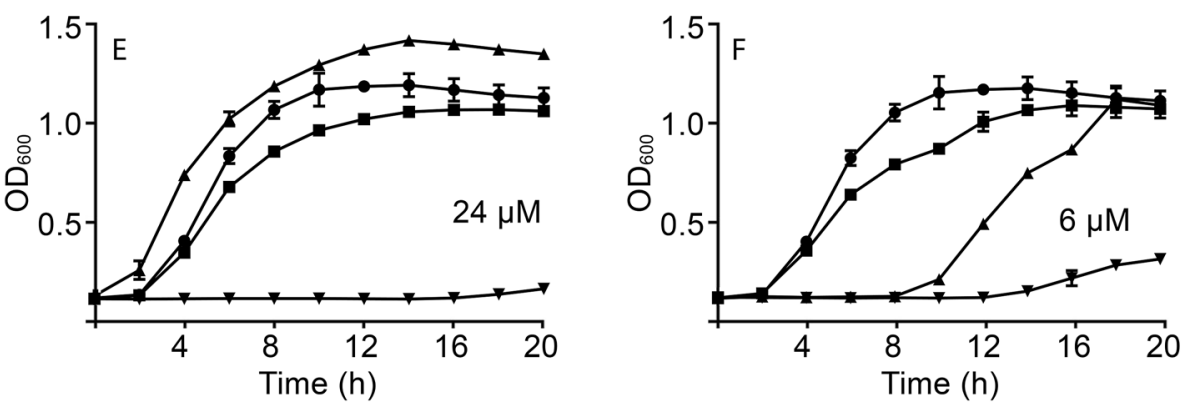

$\rightarrow$ None

- 24 (E) or 16 (F) $\mu \mathrm{g} / \mathrm{ml}$ AMK

- Zn5002 (E) or ZnPT (F)

$+24(E)$ or $16(F) \mu g / m l$ AMK +

Zn5002 (E) or ZnPT (F)

Figure 2. Effect of Zn5002 and ZnPT complexes on resistance to amikacin. A. baumannii A155, A144, A118(pJHCMW1), or K. pneumoniae JHCK1 were cultured in $100 \mu$ l Mueller-Hinton broth in microtiter plates at $37^{\circ} \mathrm{C}$ with the additions indicated to the right of each panel, and the $\mathrm{OD}_{600}$ was periodically measured. All cultures contained $0.5 \%$ DMSO. AMK, amikacin.

While the utilization of $\mathrm{ZnPT}$ as adjuvant to amikacin was very promising, drawback of this compound is its poor solubility in aqueous media and low bioavailability ${ }^{7,29}$. Addition of an amphoteric group, di(ethyleneglycol)methyl ether, to position 5 of pyrithione (compound 5002) enhances the chemical's solubility in water without increasing toxicity (Fig. 1) ${ }^{7}$. A comparison of the complexes Zn5002 and ZnPT showed that both compounds act as adjuvants to amikacin. The addition of Zn5002 plus amikacin to the nutrient medium inhibits growth and has a bactericidal effect. The active concentrations of the components, amikacin and $\mathrm{Zn}$-ionophore complex, varied 


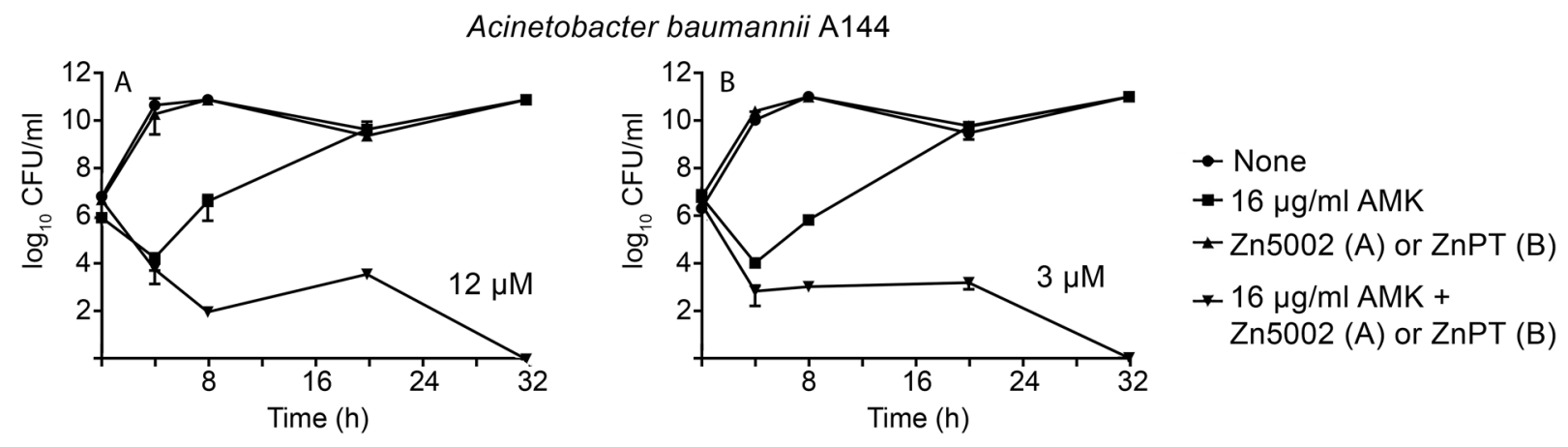

Acinetobacter baumannii A155
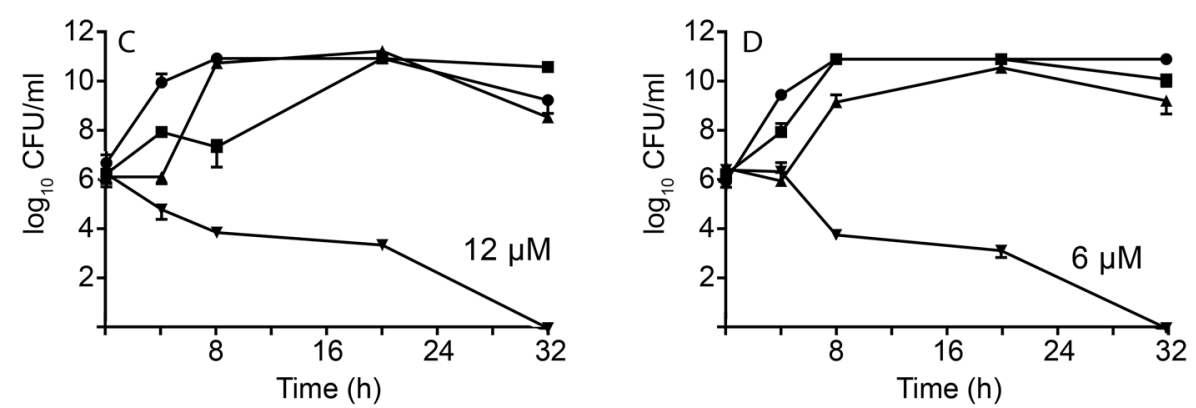
$\rightarrow$ None
-16 (C) or 8 (D) $\mu \mathrm{g} / \mathrm{ml}$ AMK
- Zn5002 (C) or ZnPT (D)
* 16 (C) or 8 (D) $\mu \mathrm{g} / \mathrm{ml}$ AMK + Zn5002 (C) or ZnPT (D)

Acinetobacter baumannii A118(pJHCMW1)
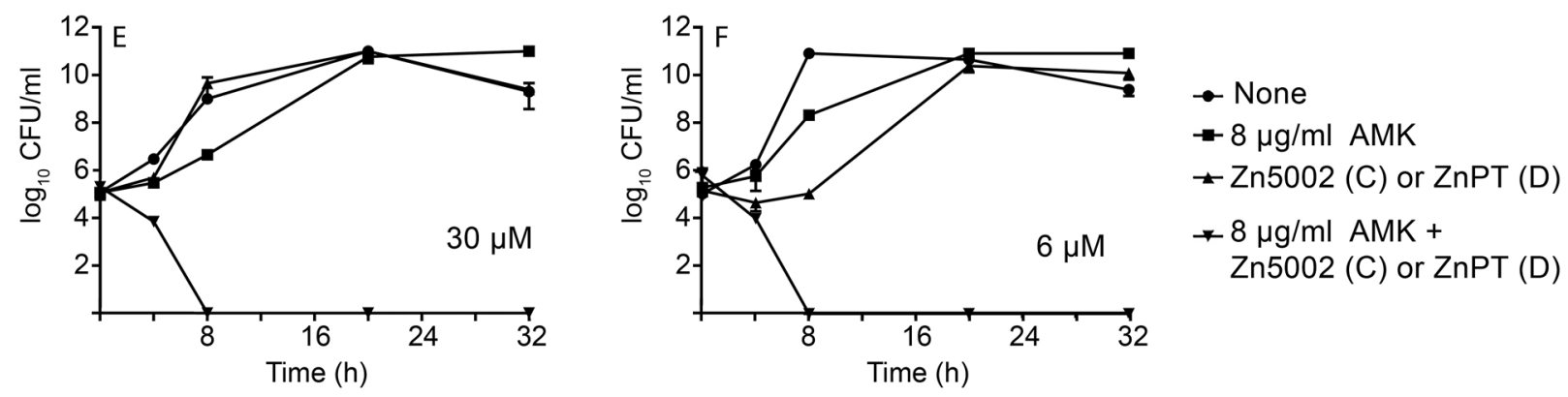

Klebsiella pneumoniae JHCK1
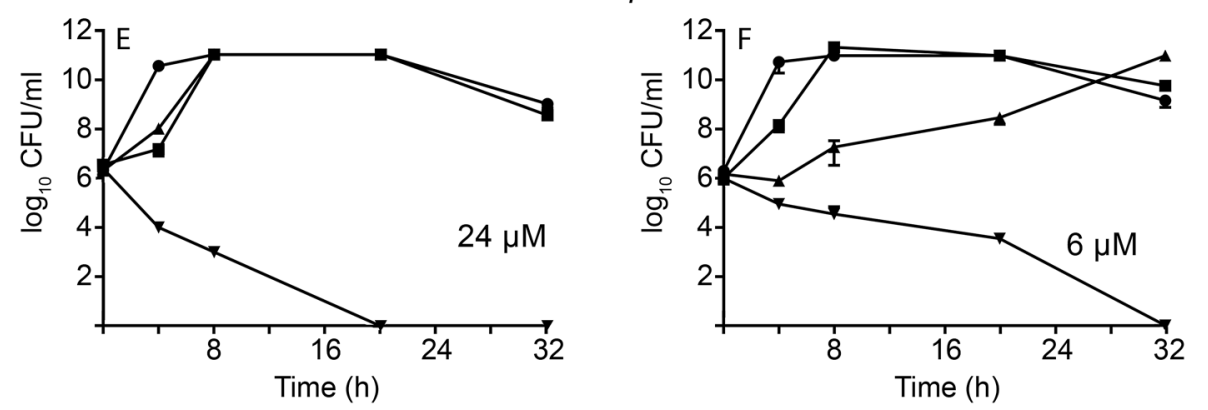

$\rightarrow$ None

- $24(E)$ or $16(F) \mu g / m l$ AMK

+ Zn5002 (E) or ZnPT (F)

$+24(\mathrm{E})$ or $16(\mathrm{~F}) \mu \mathrm{g} / \mathrm{ml} \mathrm{AMK}+$ Zn5002 (E) or ZnPT (F)

Figure 3. Time-kill assay curves for amikacin in the presence of Zn5002 and ZnPT. A. baumannii A155, A144, A118(pJHCMW1), or K. pneumoniae JHCK1 were cultured in $100 \mu$ l Mueller-Hinton containing 0.5\% DMSO until they reach $10^{6} \mathrm{CFU} / \mathrm{ml}$. At this moment the cultures were supplemented with the additions indicated to the right of each panel, the cultures were continued at $37^{\circ} \mathrm{C}$ with shaking and samples were removed periodically to determine $\mathrm{CFU} / \mathrm{ml}$. AMK, amikacin.

from strain to strain. This characteristic can be due to $a a c\left(6^{\prime}\right)-I b$ gene dosage or other mechanisms or properties that may help the resistance, such as efflux pumps or low permeability. Inspection of the results indicates that the active concentrations of Zn5002 were consistently higher than those of ZnPT, suggesting that a reduction in activity accompanied the gain in solubility in aqueous solutions. However, the fact that a highly water-soluble derivative of $\mathrm{ZnPT}$ conserved the activity indicates that further research will permit us to design other robust 
adjuvants with high water-solubility. Those compounds, whose synthesis will be carried out in the near future, will be strong potentiators to aminoglycosides to overcome resistance mediated by AAC $\left(6^{\prime}\right)-\mathrm{Ib}$.

\section{Methods}

Bacterial strains. The bacterial strains used in this study were A. baumannii $\mathrm{A} 155^{30}, \mathrm{~A} 144^{31}$, and A118(pJHCMW1) ${ }^{32}$, and K. pneumoniae JHCK1 ${ }^{33}$. A. baumannii A155 and A144 are multidrug-resistant and include $a a c\left(6^{\prime}\right)-I b$ in their genomes ${ }^{30,31}$. A. baumannii A118 is a blood isolate characterized for being susceptible to most antibiotics ${ }^{32}$. This strain was transformed with pJHCMW1, a plasmid that carries $a a c\left(6^{\prime}\right)-I b^{34}$. K. pneumoniae JHCK1 is a multidrug-resistant isolate from cerebrospinal fluid of a neonate with meningitis ${ }^{35}$.

General procedures. Routine bacterial cultures were carried out in L broth (Lennox, $1 \%$ tryptone, $0.5 \%$ yeast extract, $0.5 \% \mathrm{NaCl}$ ), with the addition of $2 \%$ agar for plates. was tested inoculating $100-\mu \mathrm{l}$ Mueller-Hinton broth in microtiter plates with the specified additions using the BioTek Synergy 5 microplate reader.

Inhibition of growth was determined by inoculating Mueller-Hinton broth $(100-\mu \mathrm{l})$ containing the indicated additions. The microtiter plates were incubated with shaking at $37^{\circ} \mathrm{C}$ in a BioTek Synergy 5 microplate reader as previously described ${ }^{20}$. The cultures' optical density values at $600 \mathrm{~nm}\left(\mathrm{OD}_{600}\right)$ were determined at regular intervals. ZnPT was purchased from MilliporeSigma, and Zn5002 was synthesized and purified to $97.87 \%$ by BioSynthesis Inc. All cultures to determine the action of zinc-ionophore complexes inhibition of resistance to amikacin or bactericidal effect included $0.5 \%$ dimethylsulfoxide (MilliporeSigma). Time-kill assays were performed as before ${ }^{20}$. Briefly, cells were cultured in Mueller-Hinton broth until they reached $10^{6} \mathrm{CFU} / \mathrm{ml}$. At this time, the compounds to be tested were added, and the cultures were continued at $37^{\circ} \mathrm{C}$ with shaking. The number of cells was determined by taking aliquots after $0,4,8,20$, and $32 \mathrm{~h}$.

\section{Data availability}

Bacterial strains used in this work are available upon request.

Received: 29 July 2021; Accepted: 23 December 2021

Published online: 07 January 2022

\section{References}

1. Abuzar, S. M. et al. Enhancing the solubility and bioavailability of poorly water-soluble drugs using supercritical antisolvent (SAS) process. Int. J. Pharm. 538, 1-13. https://doi.org/10.1016/j.ijpharm.2017.12.041 (2018).

2. Gupta, S., Kesarla, R. \& Omri, A. Formulation strategies to improve the bioavailability of poorly absorbed drugs with special emphasis on self-emulsifying systems. ISRN Pharm. 2013, 848043. https://doi.org/10.1155/2013/848043 (2013).

3. Patel, V. R. \& Agrawal, Y. K. Nanosuspension: an approach to enhance solubility of drugs. J. Adv. Pharm. Technol. Res. 2, 81-87. https://doi.org/10.4103/2231-4040.82950 (2011).

4. Garg, A. K. et al. Solubility enhancement, formulation development and antifungal activity of luliconazole niosomal gel-based system. J. Biomater. Sci. Polym. Ed. https://doi.org/10.1080/09205063.2021.1892471 (2021).

5. Savjani, K. T., Gajjar, A. K. \& Savjani, J. K. Drug solubility: importance and enhancement techniques. ISRN Pharm. 2012, 195727. https://doi.org/10.5402/2012/195727 (2012).

6. Wen, Y. et al. Azithromycin-loaded linolenic acid-modified methoxy poly(ethylene glycol) micelles for bacterial infection treatment. Drug Deliv. Transl. Res. https://doi.org/10.1007/s13346-021-00953-2 (2021).

7. Magda, D. et al. Synthesis and anticancer properties of water-soluble zinc ionophores. Cancer Res. 68, 5318-5325. https://doi.org/ 10.1158/0008-5472.CAN-08-0601 (2008).

8. Ramirez, M. S. \& Tolmasky, M. E. Amikacin: uses, resistance, and prospects for inhibition. Molecules https://doi.org/10.3390/ molecules22122267 (2017)

9. Ramirez, M. S. \& Tolmasky, M. E. Aminoglycoside modifying enzymes. Drug Resist. Updat. 13, 151-171. https://doi.org/10.1016/j. drup.2010.08.003 (2010).

10. Ramirez, M. S., Nikolaidis, N. \& Tolmasky, M. E. Rise and dissemination of aminoglycoside resistance: the $a a c\left(6^{\prime}\right)$-Ib paradigm. Front. Microbiol. 4, 121. https://doi.org/10.3389/fmicb.2013.00121 (2013).

11. Chiem, K. et al. Inhibition of aminoglycoside 6'- $N$-acetyltransferase type Ib-mediated amikacin resistance in Klebsiella pneumoniae by zinc and copper pyrithione. Antimicrob. Agents Chemother. 59, 5851-5853. https://doi.org/10.1128/AAC.01106-15 (2015).

12. Lin, D. L. et al. Inhibition of aminoglycoside $6^{\prime}-N$-acetyltransferase type Ib by zinc: reversal of amikacin resistance in Acinetobacter baumannii and Escherichia coli by a zinc ionophore. Antimicrob. Agents Chemother. 58, 4238-4241. https://doi.org/10.1128/AAC. 00129-14 (2014).

13. Li, Y., Green, K. D., Johnson, B. R. \& Garneau-Tsodikova, S. Inhibition of aminoglycoside acetyltransferase resistance enzymes by metal salts. Antimicrob. Agents Chemother. 59, 4148-4156. https://doi.org/10.1128/AAC.00885-15 (2015).

14. Cuajungco, M. P., Ramirez, M. S. \& Tolmasky, M. E. Zinc: multidimensional effects on living organisms. Biomedicines. https://doi. org/10.3390/biomedicines9020208 (2021).

15. Borg-Neczak, K. \& Tjalve, H. Effect of sodium pyridinethione on the uptake and distribution of nickel in rats, ferrets and guineapigs. Arch. Toxicol. 68, 450-458. https://doi.org/10.1007/s002040050096 (1994).

16. Di, L. \& Edward, K. in Drug-like properties: concepts, structure design, and methods Ch. 3, 15-28 (Elsevier, Amsterdam, 2008).

17. Soleimani, M. et al. Current diagnostic tools and management modalities of Nocardia keratitis. J. Ophthalmic Inflamm. Infect. 10, 36. https://doi.org/10.1186/s12348-020-00228-w (2020).

18. Torres, A., Motos, A., Battaglini, D. \& Li Bassi, G. Inhaled amikacin for severe Gram-negative pulmonary infections in the intensive care unit: current status and future prospects. Crit. Care 22, 343. https://doi.org/10.1186/s13054-018-1958-4 (2018).

19. Reeves, C. M. et al. Aminoglycoside 6'- $N$-acetyltransferase type Ib [AAC(6')-Ib]-mediated aminoglycoside resistance: phenotypic conversion to susceptibility by silver ions. Antibiotics (Basel) https://doi.org/10.3390/antibiotics10010029 (2020).

20. Magallon, J. et al. Restoration of susceptibility to amikacin by 8 -hydroxyquinoline analogs complexed to zinc. PLoS ONE 14, e0217602. https://doi.org/10.1371/journal.pone.0217602 (2019).

21. Chiem, K., Hue, F., Magallon, J. \& Tolmasky, M. E. Inhibition of aminoglycoside 6'- $N$-acetyltransferase type Ib-mediated amikacin resistance by zinc complexed with clioquinol, an ionophore active against tumors and neurodegenerative diseases. Int. J. Antimicrob. Agents 51, 271-273. https://doi.org/10.1016/j.ijantimicag.2017.08.002 (2018).

22. Ahmed, S. et al. Retention of antibiotic activity against resistant bacteria harbouring aminoglycoside- $N$-acetyltransferase enzyme by adjuvants: a combination of in-silico and in-vitro study. Sci. Rep. 10, 19381. https://doi.org/10.1038/s41598-020-76355-0 (2020). 
23. Srivastava, G. et al. Anticancer activity of pyrithione zinc in oral cancer cells identified in small molecule screens and xenograft model: implications for oral cancer therapy. Mol. Oncol. 9, 1720-1735. https://doi.org/10.1016/j.molonc.2015.05.005 (2015).

24. Zhao, C. et al. Repurposing an antidandruff agent to treating cancer: zinc pyrithione inhibits tumor growth via targeting proteasome-associated deubiquitinases. Oncotarget 8, 13942-13956. https://doi.org/10.18632/oncotarget.14572 (2017).

25. Bohlmann, L. et al. Chemical synergy between ionophore PBT2 and zinc reverses antibiotic resistance. MBio https://doi.org/10. 1128/mBio.02391-18 (2018).

26. De Oliveira, D. M. P. et al. Repurposing a neurodegenerative disease drug to treat Gram-negative antibiotic-resistant bacterial sepsis. Sci. Transl. Med. https://doi.org/10.1126/scitranslmed.abb3791 (2020).

27. Harbison-Price, N. et al. Multiple bactericidal mechanisms of the zinc ionophore PBT2. mSphere. https://doi.org/10.1128/mSphe re.00157-20 (2020).

28. Blanchard, C. et al. Zinc pyrithione improves the antibacterial activity of silver sulfadiazine ointment. mSphere. https://doi.org/ 10.1128/mSphere.00194-16 (2016).

29. Jasim, S. \& Tjalve, H. Effects of sodium pyridinethione on the uptake and distribution of nickel, cadmium and zinc in pregnant and non-pregnant mice. Toxicology 38, 327-350 (1986).

30. Arivett, B. A. et al. Draft genome of the multidrug-resistant Acinetobacter baumannii strain A155 clinical isolate. Genome Announc. 3, e0212-00215. https://doi.org/10.1128/genomeA.00212-15 (2015).

31. Vilacoba, E. et al. Draft genome sequence of an international clonal lineage 1 Acinetobacter baumannii strain from Argentina. Genome Announc. 2, e01190. https://doi.org/10.1128/genomeA.01190-14 (2014).

32. Ramirez, M. S. et al. Naturally competent Acinetobacter baumannii clinical isolate as a convenient model for genetic studies. J. Clin. Microbiol. 48, 1488-1490. https://doi.org/10.1128/JCM.01264-09 (2010).

33. Xie, G. et al. Genome sequences of two Klebsiella pneumoniae Isolates from different geographical regions, Argentina (strain JHCK1) and the United States (strain VA360). Genome Announc. 1, 00168. https://doi.org/10.1128/genomeA.00168-13 (2013).

34. Sarno, R., McGillivary, G., Sherratt, D. J., Actis, L. A. \& Tolmasky, M. E. Complete nucleotide sequence of Klebsiella pneumoniae multiresistance plasmid pJHCMW1. Antimicrob. Agents Chemother. 46, 3422-3427. https://doi.org/10.1128/AAC.46.11.3422-3427. 2002 (2002).

35. Woloj, M., Tolmasky, M. E., Roberts, M. C. \& Crosa, J. H. Plasmid-encoded amikacin resistance in multiresistant strains of Klebsiella pneumoniae isolated from neonates with meningitis. Antimicrob. Agents Chemother. 29, 315-319 (1986).

\section{Acknowledgements}

This work was supported by Public Health Service Grants 2R15AI047115 (M.E.T.) from the National Institute of Allergy and Infectious Diseases, National Institutes of Health, SC3GM125556 (M.S.R.) from the National Institute of General Medical Sciences, National Institutes of Health, and California State University Fullerton.

\section{Author contributions}

Conceptualization, M.E.T.; formal analysis, J.M., M.S.R., and M.E.T.; funding acquisition, M.S.R. and M.E.T.; methodology, J.M., P.V., C.R., S.K., K.P., C.L. O.-H., K. R., V.J., M.S.R., and M.E.T.; resources, M.S.R., and M.E.T.; writing-original draft preparation, M.E.T.; writing_review and editing, J.M., M.E.T., and M.S.R. All authors have read and agreed to the published version of the manuscript.

\section{Competing interests}

The authors declare no competing interests.

\section{Additional information}

Correspondence and requests for materials should be addressed to M.E.T.

Reprints and permissions information is available at www.nature.com/reprints.

Publisher's note Springer Nature remains neutral with regard to jurisdictional claims in published maps and institutional affiliations.

(c) (i) Open Access This article is licensed under a Creative Commons Attribution 4.0 International License, which permits use, sharing, adaptation, distribution and reproduction in any medium or format, as long as you give appropriate credit to the original author(s) and the source, provide a link to the Creative Commons licence, and indicate if changes were made. The images or other third party material in this article are included in the article's Creative Commons licence, unless indicated otherwise in a credit line to the material. If material is not included in the article's Creative Commons licence and your intended use is not permitted by statutory regulation or exceeds the permitted use, you will need to obtain permission directly from the copyright holder. To view a copy of this licence, visit http://creativecommons.org/licenses/by/4.0/.

(C) The Author(s) 2022 